\title{
MINERAL CHEMISTRY OF CLINOPYROXENE AND FELDSPARS IN THE NEOPROTEROZOIC ALKALINE DYKES OF THE BANGALORE DISTRICT, KARNATAKA, INDIA
}

\author{
H.T. MAKKONEN, K. LAAJOKI and T.C. DEVARAJU
}

\begin{abstract}
MAKKONEN, H. T.; LAAJOKI, K. and DEVARAJU, T. C. 1993. Mineral chemistry of clinopyroxene and feld spars in the Neoproterozoic alkaline dykes of the Bangalore district, Karnataka, India. Bull. Geol. Soc. Finland 65, Part II, 77-88.

The unmetamorphosed Neoproterozoic dykes of the continental intraplate alkaline magmatism studied in Southern Karnataka consist of analcime-tinguaites, tinguaites, bostonites and solvsbergites. The analcime-tinguaites, tinguaites and bostonites display pyroxene trends typical of alkaline rocks; the cores of the phenocrysts containing more diopside whereas the rims contain more hedenbergite and aegirine and the groundmass clinopyroxenes have the highest aegirine contents.

The pyroxene trends of the rocks are similar, indicating that the melts they formed from had similar fugacities of oxygen and/or similar peralkalinities. The absence of reverse zoning indicates that the melts were not intermixed.

The K-feldspar is either K-rich and Na-poor sanidine or orthoclase and is zoned with respect to sodium and sometimes also barium. The plagioclase is almost pure albite.
\end{abstract}

Key words: dykes, tinguaite, bostonite, solvsbergite, clinopyroxene, K-feldspar, electron probe data, Proterozoic, Neoproterozoic, Karnataka, India.

Makkonen, H. T. and Laajoki, K., Department of Geology, University of Oulu, Linnanmaa, SF-90570 Oulu, Finland.

Devaraju, T. C., Department of Studies in Geology, Karnataka University, Dharwad 580003, India.

\section{INTRODUCTION}

Although alkaline rocks account for less than $1 \%$ of all igneous rocks, they have been described in all continental areas, where they may be classified into two tectonic settings: 1) continental rift valley magmatism, which has produced most of alkaline rocks and 2) continental intraplate magmatism, which is the second important producer of alkaline rocks but its activity and siting are not subject to obvious tectonic control (Fitton and Upton 1987).

The stabilization of the Karnataka craton took 


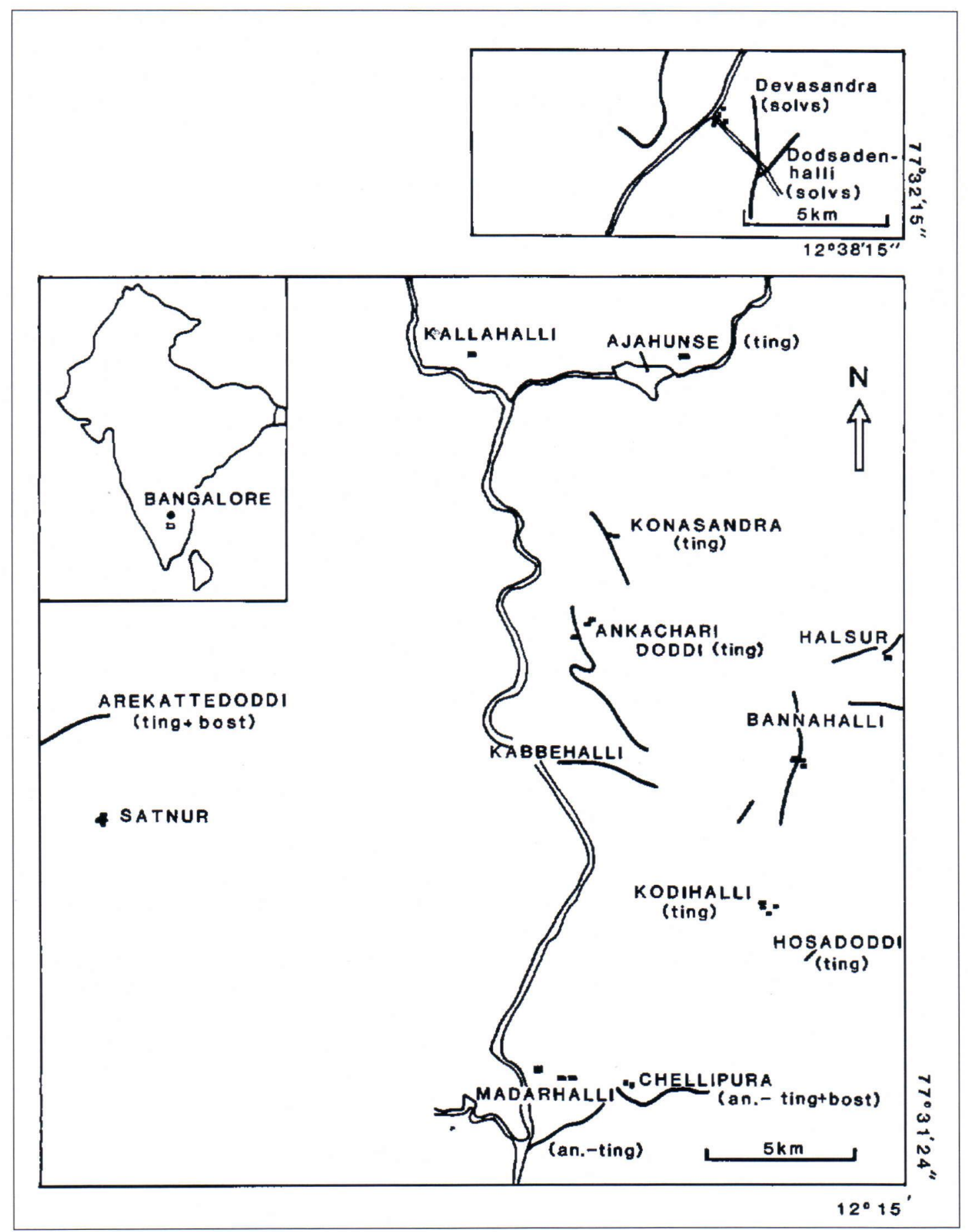

Fig. 1. Locations of the Karnataka alkaline dykes studied, their names and rock contents. 
place between the intrusions of the late Archaean Closepet granite and the unmetamorphosed Archaean/Palaeoproterozoic dolerites, the ages of

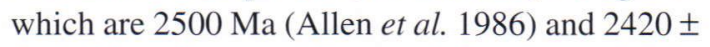
$246 \mathrm{Ma}$ (Ikramuddin and Stueber 1976), respectively. The completely unmetamorphosed alkaline rocks, which will be described in this paper, intruded some $1500 \mathrm{Ma}$ after this stabilization, as revealed by their $\mathrm{Rb}-\mathrm{Sr}$ ages of $832 \pm 40 \mathrm{Ma}$ (Ikramuddin and Stueber 1976). Since these unmetamorphosed alkaline rocks are not associated with continental rifting, they fall into the category of continental intraplate magmatism. Although there are more than 200 dykes in the area, they have been relatively little studied (see references in Ikramuddin 1974) which may be partly due to their modest sizes: they are usually less than $3 \mathrm{~m}$ wide and $15 \mathrm{~m}$ to $8 \mathrm{~km}$ long. Ikramuddin (op. cit.) studied the whole rock chemistry and $\mathrm{Rb}$-Sr-isotopes of these rocks in the Bidadi-Harohalli area and verified their extreme richness in potash ( up to $14.59 \% \mathrm{~K}_{2} \mathrm{O}$ ), their high initial ${ }^{87} \mathrm{Sr} /{ }^{86} \mathrm{Sr}$ ratio, high $\mathrm{K}, \mathrm{Rb}$ and $\mathrm{Ba}$ and low $\mathrm{Mg}, \mathrm{Ni}$ and $\mathrm{Cr}$. He concluded that they were not derived from carbonatitic or nephelinitic magma but may have been formed by partial melting of a phlogopite-rich assemblage or by a reaction between the magma and mantle rocks.

This paper, which is based on the laboratory work of Makkonen (1991), concentrates on the chemistry of the main minerals of the alkaline dykes, that occur some $50 \mathrm{~km}$ southwest of the Bidadi-Harohalli area. A summary of the geochemical and petrological study of these intrusions is given by Devaraju et al. (1989).

\section{Sampling}

For this work 12 unweathered samples were studied. They were collected from the dykes, the distributions of which are shown in Fig. 1. The total amount of dykes is 10, including Chellipura and Arekattedoddi, which are composite structures (Table 1).

\section{Analytical methods}

The microprobe analyses were performed at the
Department of Electron Optics, University of Oulu, using a JEOL JCXA 733 microanalyser. The Kfeldspars in samples DJK-39A and DJK-25 were analysed at the University of Bonn, Germany.

\section{PETROGRAPHY}

The rocks studied are analcime-tinguaites, tinguaites, bostonites and solvsbergites (Fig. 1., Table 1.). The names recommended by IUGS (Le Maitre 1989) for these rocks would be phonolite, alkali feldspar syenite and trachyte, respectively, but the traditional names are used in order to convey information on the special textures and mineralogies of the dykes. Chemically these rocks are phonolites and trachytes (Devaraju et al. 1989), while they range in texture from porphyritic to equigranular, being most commonly porphyritic. The main minerals are clinopyroxene, $\mathrm{K}$-feldspar, plagioclase and analcime (Table 1). The phenocrysts of the porphyritic rocks consist of clinopyroxene and $\mathrm{K}$ feldspar, while the groundmass minerals are clinopyroxene, K-feldspar, plagioclase and analcime. The last of which, the only feldspathoid found in the samples, is described in another paper (Devaraju et al., in prep.).

The groundmasses of the porphyritic rocks are fine-grained and hypidiomorphic-granular and occasionally display a flow structure. Their phenocrysts range between 0.3 and $8 \mathrm{~mm}$ in size. Equigranular specimens are medium-grained (1-2 $\mathrm{mm})$.

The analcime-tinguaites and tinguaites display a tinguaitic texture, while a bostonitic texture is typical of the bostonites. The bostonites and solvsbergites are markedly altered. The accessory minerals include titanite, calcite, haematite, ilmenite, pyrrhotite, biotite, epidote, magnetite, rutile, apatite and zircon.

\section{PYROXENES}

\section{Occurrence}

Subhedral, zoned clinopyroxene phenocrysts with pale brown and occasionally also greenish cores 
Table 1. The rocks of the Karnataka alkaline dykes studied and their mineral contents.

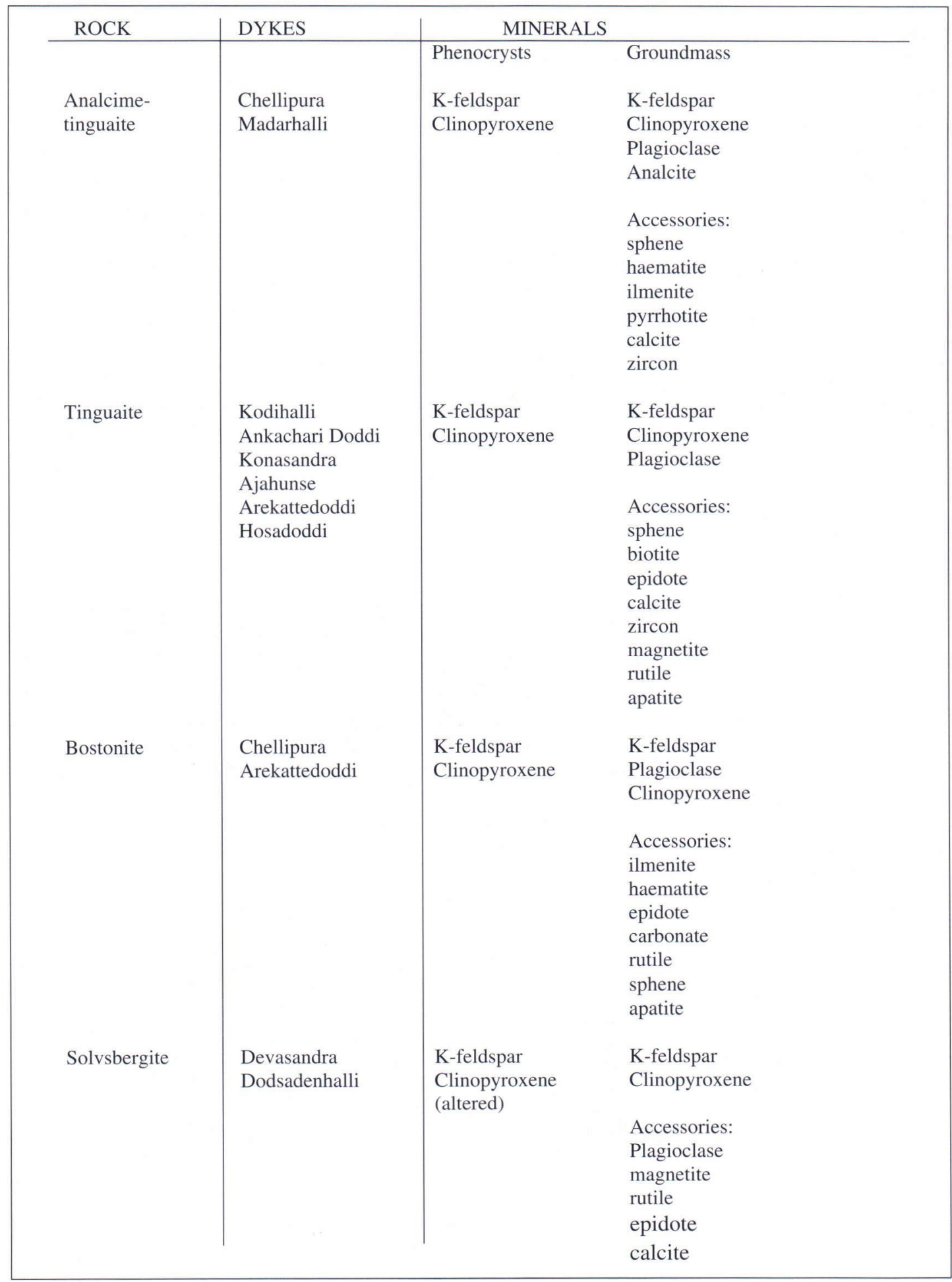


surrounded by pleochroic green rims (Fig. 2) are common in the analcime-tinguaites, tinguaites and bostonites, whereas the pyroxene phenocrysts in the solvsbergites are totally altered. Sometimes there is also a distinct mantle zone between the core and the rim. The zoning of the pyroxene is normal or oscillatory, and none of the samples studied displays reverse zoning. The boundaries between the zones are sometimes sharp, but gradational zoning is more common. The cores of the clinopyroxene phenocrysts are sometimes euhedral. The optical orientation (c $\Lambda \mathrm{X}$ ) varies from -33 degrees in the extreme diopsidic cores to +4 degrees in the rims that are richest in aegirine.

The groundmass clinopyroxenes are green, anhedral or subhedral needles and laths or, in the tinguaites, occur as a fine-grained mass. The grains having the highest aegirine content display an optical orientation $(c \Lambda X)$ of +5 degrees.

\section{Mineral chemistry}

Analcime-tinguaites. In terms of diopside, hedenbergite and aegirine end members, the compositional variation in the cores of the pyroxene phenocrysts of the analcime-tinguaites is $\mathrm{Di}_{82.7} \mathrm{Hd}_{15.0} \mathrm{Ae}_{2.3}-\mathrm{Di}_{39.5} \mathrm{Hd}_{43.6} \mathrm{Ae}_{16.9}$ (Table 2). That of the extreme aegirine-bearing rims is from

$\mathrm{Di}_{0.8} \mathrm{Hd}_{26.0} \mathrm{Ae}_{73.2} \quad$ (Chellipura dyke) to $\mathrm{Di}_{0.2} \mathrm{Hd}_{10.6} \mathrm{Ae}_{89.2}$ (Madarhalli dyke) and that of the groundmass clinopyroxenes from $\mathrm{Di}_{7.0} \mathrm{Hd}_{30.2} \mathrm{Ae}_{62.8}$ to $\mathrm{Di}_{1.2} \mathrm{Hd}_{25.0} \mathrm{Ae}_{73.8}$.

Tinguaites. The cores of the pyroxenes in the tinguaites (Table 2) of Arekattedoddi and Hosadoddi are $\mathrm{Di}_{68.7} \mathrm{Hd}_{26.9} \mathrm{Ae}_{4.4}$ and $\mathrm{Di}_{87.3} \mathrm{Hd}_{11.6} \mathrm{Ae}_{1.1}$,

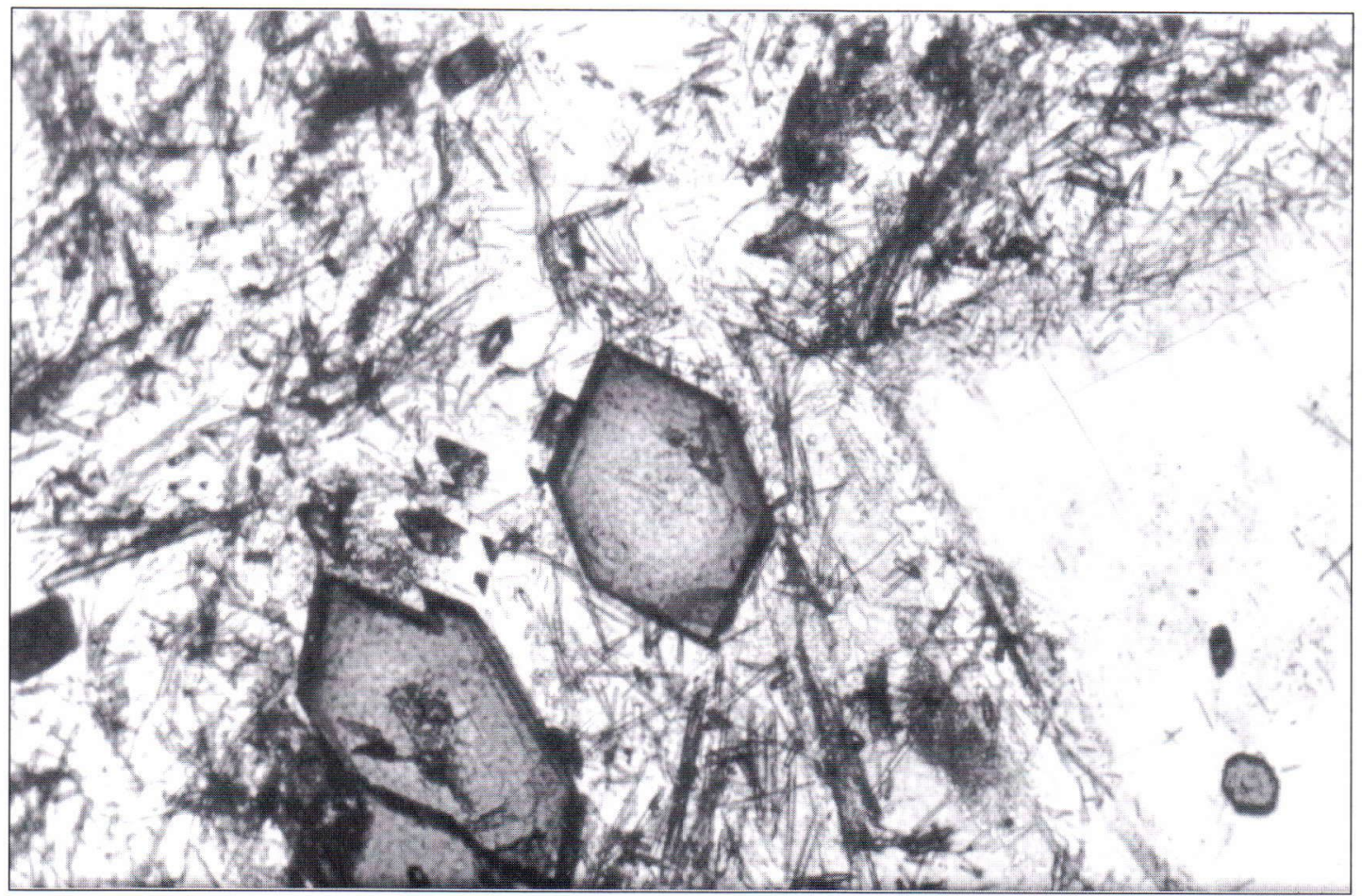

Fig. 2. Photomicrograph of zoned clinopyroxene phenocrysts. Single polar. Field of view is about $1 \mathrm{~mm} \times 1.4 \mathrm{~mm}$. 
Table 2. Results of the analyses.

Representative analyses of clinopyroxenes

$\mathrm{wt} \%$

$\begin{array}{llllllllll}1 & 2 & 3 & 4 & 5 & 6 & 7 & 8 & 9\end{array}$

$\begin{array}{lcrrrrrrrr}\mathrm{SiO}_{2} & 49.52 & 50.21 & 52.06 & 50.26 & 50.12 & 53.17 & 50.89 & 49.10 & 48.95 \\ \mathrm{TiO}_{2} & 0.79 & 2.12 & 0.37 & 0.32 & 0.36 & 0.25 & 0.40 & 0.63 & 0.76 \\ \mathrm{Al}_{2} \mathrm{O}_{3} & 2.18 & 1.85 & 0.73 & 1.07 & 0.92 & 1.04 & 1.68 & 2.07 & 2.00 \\ \mathrm{Fe}_{2} \mathrm{O}_{3} & 5.73 & 20.97 & 0.84 & 6.50 & 10.92 & 0.00 & 4.16 & 7.34 & 11.01 \\ \mathrm{FeO} & 12.55 & 6.47 & 8.47 & 11.22 & 11.13 & 5.08 & 10.41 & 10.85 & 9.91 \\ \mathrm{MnO} & 0.95 & 0.94 & 0.24 & 0.81 & 0.95 & 0.16 & 0.51 & 0.97 & 1.01 \\ \mathrm{MgO} & 6.29 & 0.19 & 12.48 & 6.92 & 4.04 & 15.21 & 9.00 & 6.47 & 6.39 \\ \mathrm{CaO} & 19.04 & 7.85 & 22.26 & 18.23 & 15.65 & 22.68 & 20.49 & 19.11 & 19.13 \\ \mathrm{Na} & 2.32 & 9.45 & 0.62 & 2.77 & 4.46 & 0.50 & 1.72 & 2.41 & 2.64 \\ \mathrm{~K}_{2} \mathrm{O} & 0.02 & 0.03 & 0.00 & 0.00 & 0.01 & 0.00 & 0.00 & 0.02 & 0.00 \\ \mathrm{~V}_{2} \mathrm{O}_{3} & 0.06 & 0.12 & 0.01 & 0.09 & 0.12 & 0.03 & 0.06 & 0.08 & 0.06 \\ \mathrm{~T}_{3} & & & & & & & & & \\ \mathrm{Total} & 99.45 & 100.2098 .08 & 98.19 & 98.68 & 98.12 & 99.32 & 99.05 & 101.86\end{array}$

Sructural formula based on 6 oxygens and 4 cations

$\begin{array}{llllllllll}\mathrm{Si} & 1.930 & 1.946 & 1.986 & 1.972 & 1.977 & 1.990 & 1.953 & 1.919 & 1.906 \\ \mathrm{Al} & 0.100 & 0.084 & 0.033 & 0.049 & 0.043 & 0.045 & 0.076 & 0.095 & 0.091 \\ \mathrm{Ti} & 0.023 & 0.062 & 0.011 & 0.009 & 0.011 & 0.007 & 0.012 & 0.019 & 0.023 \\ \mathrm{Fe}^{3+} & 0.168 & 0.612 & 0.024 & 0.192 & 0.324 & 0.000 & 0.120 & 0.216 & 0.252 \\ \mathrm{Fe}^{2+} & 0.409 & 0.210 & 0.270 & 0.368 & 0.367 & 0.159 & 0.334 & 0.355 & 0.323 \\ \mathrm{Mn} & 0.031 & 0.031 & 0.008 & 0.026 & 0.032 & 0.005 & 0.017 & 0.033 & 0.033 \\ \mathrm{Mg} & 0.366 & 0.012 & 0.710 & 0.404 & 0.238 & 0.848 & 0.515 & 0.377 & 0.371 \\ \mathrm{Ca} & 0.795 & 0.327 & 0.911 & 0.766 & 0.662 & 0.909 & 0.842 & 0.800 & 0.799 \\ \mathrm{Na} & 0.175 & 0.710 & 0.046 & 0.211 & 0.342 & 0.036 & 0.129 & 0.183 & 0.200 \\ \mathrm{~K} & 0.001 & 0.002 & 0.000 & 0.000 & 0.000 & 0.000 & 0.000 & 0.001 & 0.000 \\ \mathrm{~V} & 0.002 & 0.004 & 0.001 & 0.003 & 0.004 & 0.001 & 0.002 & 0.002 & 0.002\end{array}$

Molecular per cent of end-member molecules

$\begin{array}{lrrrrrrrrr}\text { Di } & 36.4 & 1.2 & 68.7 & 40.1 & 24.3 & 81.0 & 51.7 & 39.8 & 40.0 \\ \text { Hd } & 45.5 & 25.0 & 26.9 & 39.0 & 40.8 & 15.6 & 35.3 & 40.9 & 38.4 \\ \text { Ae } & 18.1 & 73.8 & 4.4 & 20.9 & 34.9 & 3.4 & 13.0 & 19.3 & 21.6\end{array}$

1. Chellipura, analcime-tinguaite, core of phenocryst, (DJK-4)

2. Chellipura, analcime-tinguaite, groundmass, (DJK-4)

3. Arekattedoddi, tinguaite, core of phenocryst, (DJK-39)

4. Arekattedoddi, tinguaite, mantle of phenocryst, (DJK-39)

5. Arekattedoddi, tinguaite, rim of phenocryst, (DJK-39)

6. Chellipura, bostonite, core of phenocryst, (DJK-13)

7. Chellipura, bostonite, mantle of phenocryst, (DJK-13)

8. Chellipura, bostonite, rim of phenocryst, (DJK-13)

9. Chellipura, bostonite, groundmass, (DJK-13) 


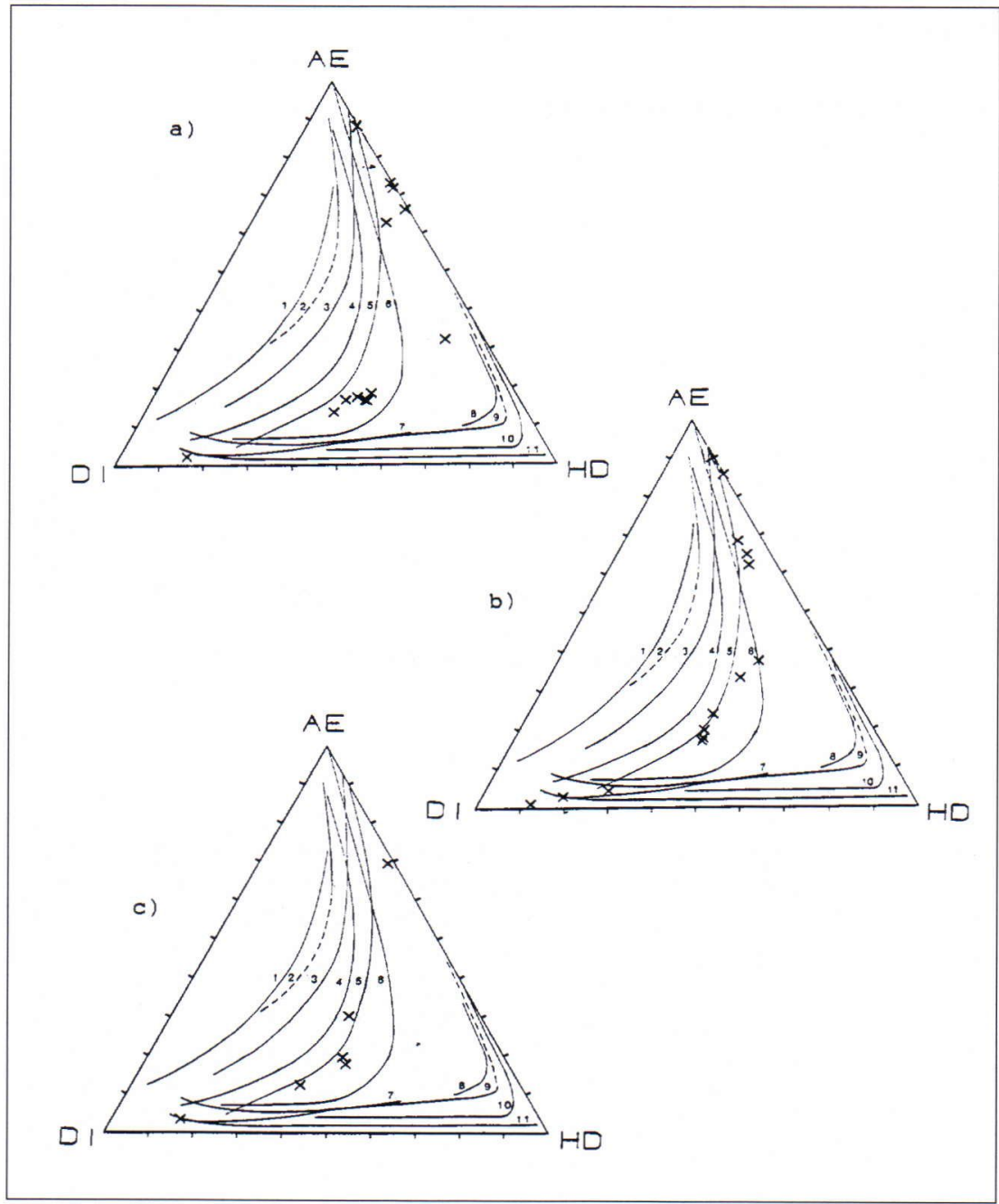

Fig. 3. Clinopyroxenes of $a$. analcime-tinguaites, $b$ ) tinguaites and c) bostonites plotted (crosses) on Di-Hd-Ae-diagrams and compared with pyroxene trends from other alkaline rocks. Undersaturated: 1) Auvergne (Varet 1969), 2) Lovozero (Bussen and Sakharov 1972), 3) Itapirapua (Gomes et al. 1970), 4) Uganda (Tyler and King 1967), 5) Morotu (Yagi 1966), 6) South Qoroq centre (Stephenson 1972) 10) Ilimaussaq (Larsen 1976). Oversaturated: 7) Alkalibasalts of Japan (Aoki 1964), 8) Pantellerites (Nicholls and Carmichael 1969), 9) Nandewar (Abbott 1969), 11) Skaergaard (not alkaline) (Brown and Vincent 1963).

respectively, while the cores at Kodihalli are hedenbergite. The zoning at Ankachari Doddi, Konasandra and Ajahunse is weaker, and the cores consist of aegirine-augite of compositions varying . between $\mathrm{Di}_{34.1} \mathrm{Hd}_{41.9} \mathrm{Ae}_{24.0}$ and $\mathrm{Di}_{6.6} \mathrm{Hd}_{31.2} \mathrm{Ae}_{62.2}$. The rims of the phenocrysts are aegirine-augite, as at Kodihalli $\left(\mathrm{Di}_{5.7} \mathrm{Hd}_{29.3} \mathrm{Ae}_{65.0}\right)$, or aegirine. The clinopyroxene grains in the groundmasses of the tinguaites are aegirine-augite as at Ajahunse $\left(\mathrm{Di}_{16.9} \mathrm{Hd}_{45.5} \mathrm{Ae}_{37.6}\right)$ or aegirine as in the samples from Hosadoddi $\left(\mathrm{Di}_{0.4} \mathrm{Hd}_{13.7} \mathrm{Ae}_{85.9}\right)$ and Ankachari Doddi $\left(\mathrm{Di}_{1.0} \mathrm{Hd}_{8.8} \mathrm{Ae}_{90.2}\right)$.

Bostonites. The pyroxene phenocrysts in the 
bostonitic unit of the Chellipura dyke have three main zones, a core, a mantle surrounding the core and an outermost rim, the compositions of which are $\mathrm{Di}_{81.0} \mathrm{Hd}_{15.6} \mathrm{Ae}_{3.4}, \quad \mathrm{Di}_{51.7} \mathrm{Hd}_{35.3} \mathrm{Ae}_{13.0}$ and $\mathrm{Di}_{39.8} \mathrm{Hd}_{40.9} \mathrm{Ae}_{19.3}$, respectively (Table 2). The pyroxene composition in the bostonitic unit of the Arekattedoddi dyke varies from $\mathrm{Di}_{29.9} \mathrm{Hd}_{39.7} \mathrm{Ae}_{30.4}$ in the core to $\mathrm{Di}_{1.8} \mathrm{Hd}_{28.7} \mathrm{Ae}_{69.5}$ in the rim. The groundmass pyroxene microliths of the bostonites in these dykes are aegirine-augite and aegirine.

Solvsbergites. The pyroxene in the solvsbergite samples is intensely altered, and only few analyses could be performed, while that in the Devasandra dyke groundmass has a composition of $\mathrm{Di}_{3.0} \mathrm{Hd}_{10.5} \mathrm{Ae}_{86.5}$.

Summary. The compositions of the pyroxenes are plotted on a Di-Hd-Ae diagram in Figure 3. The analcime-tinguaites, tinguaites and bostonites display pyroxene trends typical of alkaline rocks (Stephenson 1972, Larsen 1976, Mitchell and Platt 1978, Platt and Woolley 1986, Woolley and Platt 1986). The cores of the phenocrysts contain more diopside, whereas the rims and the groundmass clinopyroxenes contain more hedenbergite and aegirine. The trends are affected by the oxygen fugacities and/or peralkalinities of the magmas which the pyroxenes crystallized from (Larsen 1976, Mitchell and Platt 1978, Platt and Woolley 1986, Woolley and Platt 1986). Similar pyroxene trends in the analcime-tinguaites, tinguaites and bostonites of the Bangalore district indicate that their melts had similar oxygen fugacities and/or similar peralkalinities. The absence of reverse zoning indicates that the magmas were not intermixed.

The pyroxenes are also heterogeneous with respect to titanium content, the cores and mantles of

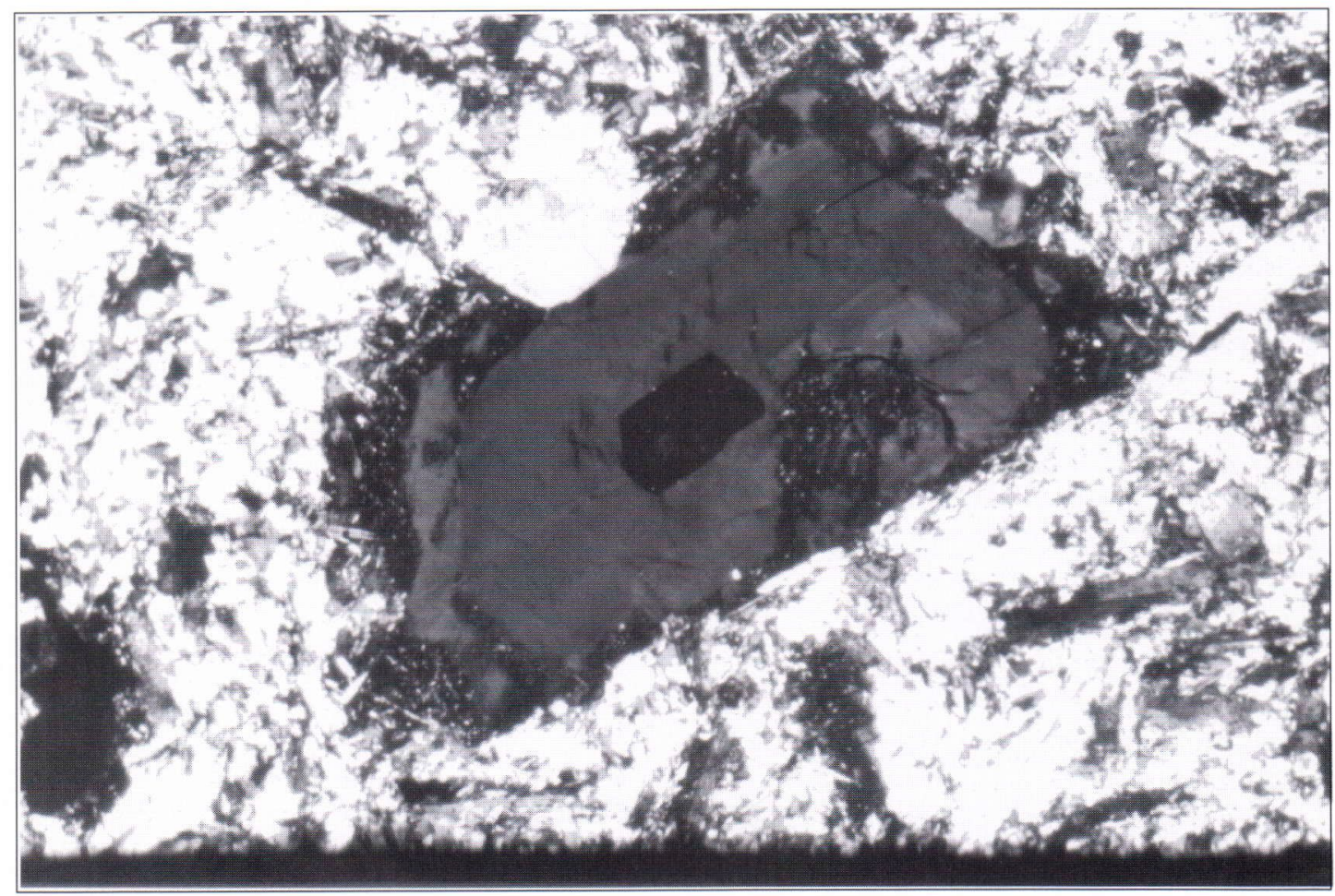

Fig. 4. Photomicrograph of zoned K-feldspar phenocryst. Crossed polars. Field of view is about $4 \mathrm{~mm} \times 1.5 \mathrm{~mm}$ 
the phenocrysts usually containing less titanium than the rims and groundmass grains. A low Ti content may be attributed to a high formation temperature (Thompson 1974) and indicates that the cores and mantles crystallized at a higher temperature than the rims and groundmass grains, which crystallized quickly after intrusion of the magma.

The zoning displayed by the pyroxene is related to its non-equilibrium crystallization and metastable incorporation of $\mathrm{Ti}$ and $\mathrm{Al}$ in its structure. The compositions of the aegirines studied support the suggestion of Ranlov and Dymek (1991) that there is a solid solution between aegirine $\left(\mathrm{NaFeSi}_{2} \mathrm{O}_{6}\right)$ and 1 to $26 \mathrm{~mol} \% \mathrm{NaFe}_{0.0-0.5} \mathrm{Ti}_{0.0-0.5} \mathrm{Si}_{2} \mathrm{O}_{6}$.

\section{K-FELDSPARS}

\section{Occurrence}

In terms of the $2 \mathrm{~V}$-angle, the $\mathrm{K}$-feldspar of the dykes is sanidine in the tinguaites and solvsbergites and also in the analcime-tinguaites excluding the Madarhalli dyke, in which the K-feldspar is orthoclase, as also in the bostonites.

The K-feldspar is usually saussuritized, and Carlsbad twinning is common. The phenocrysts are subhedral or euhedral and often mantled by albite. Zoning is common in the phenocrysts of every rock type, but is best developed in those of the tinguaites (Fig.4). The groundmass K-feldspar is subhedral to anhedral.

\section{Mineral chemistry}

The orthoclase components (Table 3 and Fig. 5) show the majority of the sanidines to be K-bearing sanidines, as they contain more than $80 \%$ orthoclase (Smith and Brown 1988). Their anorthite content is mostly less than $0.2 \%$.

In terms of element chemistry, the K-feldspars are zoned in sodium and sometimes also in barium. Barium is enriched in the cores of the K-feldspar phenocrysts, but the zoning of sodium varies. In some of the samples the groundmass grains and the
Table 3. Results of the analyses.

Representative analyses of K-feldspars in the Karnataka alkaline dykes.

$\begin{array}{lllllll}1 & 2 & 3 & 4 & 5 & 6\end{array}$

$\mathrm{wt} \%$

$\begin{array}{lrrrrrr}\mathrm{SiO}_{2} & 65.01 & 64.45 & 64.32 & 64.77 & 61.40 & 64.11 \\ \mathrm{TiO}_{2} & 0.00 & 0.01 & 0.00 & 0.00 & 0.02 & 0.00 \\ \mathrm{Al}_{2} \mathrm{O}_{3} & 18.03 & 17.66 & 17.83 & 17.89 & 18.02 & 17.54 \\ \mathrm{FeO} & 0.37 & 0.03 & 0.01 & 0.07 & 0.87 & 0.71 \\ \mathrm{MgO} & 0.00 & 0.00 & 0.00 & 0.00 & 0.00 & 0.00 \\ \mathrm{CaO} & 0.00 & 0.30 & 0.01 & 0.00 & 0.00 & 0.00 \\ \mathrm{Na}_{2} \mathrm{O} & 1.25 & 0.37 & 0.35 & 0.23 & 0.53 & 0.44 \\ \mathrm{~K}_{2} \mathrm{O} & 14.00 & 15.70 & 15.64 & 16.91 & 15.16 & 16.29 \\ \mathrm{BaO} & \text { n.d. } & \text { n.d. } & \text { n.d. } & 0.36 & 3.73 & 0.72\end{array}$

$\begin{array}{lllllll}\text { Total } & 98.71 & 98.59 & 98.22 & 100.24 & 99.75 & 99.83\end{array}$

Structural formula based on 32 oxygens

$\begin{array}{lrrrrrr}\mathrm{Si} & 12.067 & 12.066 & 12.068 & 12.033 & 11.863 & 12.021 \\ \mathrm{Ti} & 0.000 & 0.001 & 0.000 & 0.000 & 0.003 & 0.000 \\ \mathrm{Al} & 3.944 & 3.896 & 3.943 & 3.917 & 4.103 & 3.876 \\ \mathrm{Fe} & 0.058 & 0.004 & 0.002 & 0.011 & 0.141 & 0.111 \\ \mathrm{Mg} & 0.000 & 0.000 & 0.000 & 0.000 & 0.000 & 0.000 \\ \mathrm{Ca} & 0.000 & 0.060 & 0.003 & 0.000 & 0.000 & 0.000 \\ \mathrm{Na} & 0.450 & 0.133 & 0.126 & 0.083 & 0.199 & 0.160 \\ \mathrm{~K} & 3.314 & 3.751 & 3.744 & 4.008 & 3.736 & 3.897 \\ \mathrm{Ba} & \text { n.d. } & \text { n.d. } & \text { n.d. } & 0.026 & 0.280 & 0.053\end{array}$

Molecular per cent of end-member molecules

$\begin{array}{rrrrrrr}\text { Or } & 88.1 & 95.1 & 96.7 & 98.0 & 95.0 & 96.1 \\ \mathrm{Ab} & 11.9 & 3.4 & 3.2 & 2.0 & 5.0 & 3.9 \\ \mathrm{An} & 0.0 & 1.5 & 0.1 & 0.0 & 0.0 & 0.0\end{array}$

1. Kodihalli, tinguaite, core of phenocryst, (DJK-18)

2. Arekattedoddi, tinguaite, core of phenocryst,(DJK39)

3. Chellipura, bostonite, phenocryst, (DJK-13)

4. Arekattedoddi, bostonite, (DJK-39A)

5 . Devasandra, solvsbergite, core of phenocryst, (DJK25)

6. Devasandra, solvsbergite, rim of phenocryst, (DJK25) 
outer zones of the phenocrysts contain more sodium than the cores, but in other samples the relation is reversed.

\section{PLAGIOCLASE}

The plagioclase which forms anhedral grains in the groundmass or mantles $\mathrm{K}$-feldspar is almost pure albite $\left(\mathrm{Ab}_{98.9-99.7}\right)$ ( Fig. 5). Its iron content is low.

\section{CONCLUSIONS AND DISCUSSION}

The similar pyroxene trends found in the analcimetinguaites, tinguaites and bostonites of the Bangalore district prove that the melts had similar fugacities of oxygen and/or similar peralkalinities. The absence of reverse zoning indicates that no intermixing of the magmas took place.

The clinopyroxene and K-feldspar phenocrysts crystallized at a higher temperature, before the magmas intruded into their present locations, whereas the groundmass minerals, i.e. clinopyroxene, K-feldspar, albite and analcime, crystallized rapidly after intrusion of the magmas.

The consistent less aegirine contents of cores as compared to rims of pyroxene phenocrysts and groundmass pyroxenes suggest that the magma from which they were formed was initially less alkaline.

The K-feldspars of the alkaline dykes are zoned in sodium and sometimes also in barium. Barium is enriched in the cores of the K-feldspar phenocrysts, but the zoning of sodium varies.
An

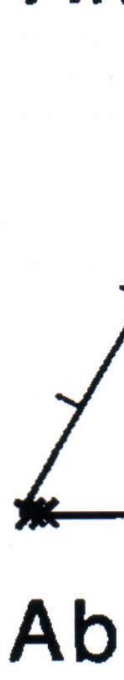

Fig. 5. Feldspars of the Karnataka alkaline dykes plotted on a Ab-An-Or-diagram. 
ACKNOWLEDGEMENTS: This paper is a contribution to IGCP-project 314. The authors are grateful to Dr. B. Spiering of the University of Bonn, Germany, for help with the microprobe analyses of the $K$ feldspars in samples DJK-39A and DJK-25. The other microanalyses were performed at the Department of Electron Optics, University of Oulu, the staff of which are acknowledged for theirtechnical assistance. The English of the manuscript was improved by Malcolm Hicks. The thin sections were made by Ulla Paakkola and the map and the diagrams were drawn by Kristiina Karjalainen. Grants from the Academy of Finland and the Research Foundation for Finnish Natural Resources are acknowledged by H. Makkonen and K. Laajoki.

\section{REFERENCES}

Abbott, M. J.,1969. Petrology of the Nandewar volcano, N.S.W. Australia. Contributions to Mineralogy and Petrology 20, 115-134.

Allen, P., Condie, K. C. and Bowling, G. P., 1986. Geochemical characteristics and possible origins of the southern Closepet batholith, south India. Journal of Geology 94, 283-299.

Aoki, K., 1964. Clinopyroxenes from alkaline rocks of Japan. American Mineralogist 49, 1199-1223.

Brown, G. M. and Vincent, E.A., 1963. Pyroxenes from the late stages of fractionation of the Skaergaard intrusion, East Greenland. Journal of Petrology 4, 175-197.

Bussen, I. V. and Sakharov, A. S., 1972. Petrology of the Lovozero alkaline massif (in Russian). Nauka, Leningrad. $296 \mathrm{pp}$.

Devaraju, T.C., Laajoki, K., Makkonen, H., Jamkhandi, M.S.R., Khanadali, S.D. and Hoernes, S., 1989. Late Proterozoic Alkaline Dyke Swarms of Southern Karnataka, India. 28th International Geological Congress. July 9-19, 1989, Washington, D. C., USA, Abstracts.

Devaraju, T. C., Laajoki, K. and Makkonen, H. (in preparation) Analcite in the peralkaline dykes of Southern Karnataka, India.

Fitton, J. G. and Upton, B. G. J., 1987. Introduction. In: Fitton, J. G. and Upton, B. G. J. (eds): Alkaline Igneous Rocks, p. IX-XIV. Geological Society Special Publications 30. Blackwell Scientific Publications, Oxford.

Gomes, C. De B., Moro, S. L. and Dutra, C. V., 1970. Pyroxenes from the alkaline rocks of Itapirapua, Sao
Paolo, Brazil. American Mineralogist 55, 224-230.

Ikramuddin, M., 1974. Geochemistry and geochronology of Precambrian dykes from Mysore state, India. Miami University, Ohio (unpublished).

Ikramuddin, M. and Stueber, A. M., 1976. Rb-Sr ages of Precambrian dolerite and alkaline dykes, southeast Mysore State, India. Lithos 9, 235-241.

Larsen, L. M., 1976. Clinopyroxenes and coexisting mafic minerals from the alkaline Ilimaussaq intrusion, South Greenland. Journal of Petrology 17, 258-290.

Le Maitre, R. W. (Ed.), 1989. A Classification of Igneous Rocks and Glossary of Terms: Recommendations of the International Union of Geological Sciences Subcommission on the Systematics of Igneous Rocks. Blackwell Scientific Publications, Oxford. 193 pp.

Makkonen, H., 1991. Bangaloren alueen (Intia) alkalikivijuonten petrografia ja mineraalikemia. (Abstract: Petrography and mineral chemistry of alkaline dykes in the Bangalore district, India). Res Terrae (B) 13, Oulu. $58 \mathrm{pp}$.

Mitchell, R. H. and Platt, R. G., 1978. Mafic mineralogy of ferroaugite syenite from the Coldwell alkaline complex, Ontario, Canada. Journal of Petrology 19, 627-651.

Nicholls, J. and Carmichael, I. S. E., 1969. Peralkaline acid liquids: A petrological study. Contributions to Mineralogy and Petrology 20, 268-294.

Platt, R. G. and Woolley, A. R., 1986. The mafic mineralogy of the peralkaline syenites and granites of the Mulanje Complex, Malawi. Mineralogical Magazine 50, 85-99.

Ranlov, I. and Dymek, R. F., 1991. Compositional zoning in hydrothermal aegirine from fenites in the 
Proterozoic Gardar province, South Greenland. European Journal of Mineralogy 3, 837-853.

Smith, J. V. and Brown, W. L., 1988. Feldspar Minerals. Vol 1, Crystal Structures, Physical, Chemical and Microtextural properties. Springer-Verlag, Berlin. 828 pp.

Stephenson, D., 1972. Alkali clinopyroxenes from nepheline syenites of the South Qoroq Centre, South Greenland. Lithos 5, 187-201.

Thompson, R. N., 1974. Some high-pressure pyroxenes. Mineralogical Magazine 39, 768-787.

Tyler, R. C. and King, B. C., 1967. The pyroxenes of the alkaline igneous complexes of Eastern Uganda.
Mineralogical Magazine 280, 5-22.

Varet, J., 1969. Les pyroxenes des phonolites du Cantal (Auvergne, France). Neues Jahrbuch für Mineralogie Monatshehte 4, 174-184.

Woolley, A. R. and Platt, R. G., 1986. The mineralogy of nepheline syenite complexes from the northern part of the Chilwa Province, Malawi. Mineralogical Magazine 50, 597-610.

Yagi, K., 1966. The system acmite-diopside and its bearing on the stability relations of natural pyroxenes of the acmite-hedenbergite-diopside series. American Mineralogist 51, 976-1000. 